\title{
31. BIOSTRATIGRAPHIC SYNTHESIS, LEG 20, DSDP
}

\author{
Helen P. Foreman, Department of Geology, Oberlin College, Oberlin, Ohio \\ Heinz Hekel, Geological Survey of Queensland, Brisbane, Australia \\ Robert H. Hoskins, New Zealand Geological Survey, Lower Hutt, New Zealand \\ and \\ Valeri A. Krasheninnikov, Geological Institute of the Academy of Sciences of the USSR, Moscow, USSR
}

\section{INTRODUCTION}

\section{Setting}

Leg 20, which cruised from Yokohama, Japan, to Suva, Fiji Islands, drilled 12 holes at eight sites as follows:

Site 194: $33^{\circ} 58.66^{\prime} \mathrm{N} ; 148^{\circ} 48.64^{\prime} \mathrm{E}$

Site 195: $32^{\circ} 46.5^{\prime} \mathrm{N} ; 146^{\circ} 59.0^{\prime} \mathrm{E}$

Site 196: $30^{\circ} 06.97^{\prime} \mathrm{N} ; 148^{\circ} 34.49^{\prime} \mathrm{E}$

Site 197: $30^{\circ} 17.44^{\prime} \mathrm{N} ; 147^{\circ} 40.46^{\prime} \mathrm{E}$

Site 198: $25^{\circ} 49.54^{\prime} \mathrm{N} ; 154^{\circ} 35.05^{\prime} \mathrm{E}$

Site 199: $13^{\circ} 30.78^{\prime} \mathrm{N} ; 156^{\circ} 10.34^{\prime} \mathrm{E}$

Site 200: $12^{\circ} 50.20^{\prime} \mathrm{N} ; 156^{\circ} 46.96^{\prime} \mathrm{E}$

Site 201: $12^{\circ} 49.89^{\prime} \mathrm{N} ; 156^{\circ} 44.59^{\prime} \mathrm{E}$

Site 202: $12^{\circ} 48.90^{\prime} \mathrm{N} ; 156^{\circ} 57.15^{\prime} \mathrm{E}$

The location of Leg 20 sites in relation to bathymetry is shown in Figure 1. More detailed bathymetry is shown in the sections dealing with the background to the sites and site data in Chapters 2-9.

Holes at Sites 194 to 199 were all drilled in abyssal depths and at Sites 200 to 202 on the top of a seamount.

Site 194 is located on the abyssal floor of the northwest Pacific basin, 630 kilometers east of the Japan Trench in 5754 meters of water, and more than 40 kilometers from any large seamounts.

Holes at Site 195 were drilled in the northwest Pacific basin floor in 5968 meters of water 130 kilometers south of Site 194 and also approximately 630 kilometers east of the Izu-Bonin Trench. The site is surrounded by smooth sea floor with the nearest seamount 130 kilometers away.

Drilled in 6194 meters and 6153 meters of water, respectively, holes at Sites 196 and 197 were drilled in the southwest part of the northwest Pacific basin floor. Site 196 is surrounded by very low relief and Site 197 is on a slight topographic high.

Site 198 is again a deep-water site located in the northwestward deepening abyssal basin, approximately 200 kilometers north of Marcus Island in 5858 meters water depth. This site is bordered on either side by northwestsoutheast trending topographic highs which are approximately 50 kilometers from the site.

The eastern margin of the Caroline Abyssal Plain north of the Caroline Islands is the location for Sites 199 to 202. The hole at Site 199, 1000 kilometers east of Guam, was drilled on the abyssal floor in 6100 meters at a northeastern extension of the Caroline Abyssal Plain. This deep-water site is almost surrounded by seamounts, on one of which (the Ita Mai Tai Guyot) the Holes of Sites 200 to 202 were drilled in approximately 1500 meters water depth. The Ita Mai Tai Guyot is 65 kilometers south of Site 199 and rises 4600 meters from the abyssal floor.

\section{Abundance and Preservation of Fossil Groups}

Figures 2 and 3 have been included to aid the reader in selecting samples for further study. They indicate the abundance and preservation of various fossil groups encountered. In requesting samples it should be kept in mind that Radiolaria in Cores 194-3, 194-4, 194-5, 195-3, and 195-4 were recovered only from cherts in the core catcher, in Core 195-5 from the center bit, and Core 195A-1 from the bit; nannofossils in Cores 195-4, 195-5, and 195A-1 were recovered only from the center bit.

\section{COMPARISON OF AGE AND ZONAL ASSIGNMENTS}

For Holes 194, 195, 195B, 196, and 198 it is not possible to compare zones for the various faunal groups because in the cases where two or more groups occur together, the interval cored has not yet been defined by a zone or defined zones could not be recognized. Therefore Figures 4 to 7 give, in general, only comparative age assignments according to the three main faunal groups studied-foraminifera, nannofossils, and radiolarians.

For Holes 199, 200, 200A, and 202 where reocvery of both nannofossils and foraminifera was much better, zonal assignments are given in Figures 8-10.

\section{Early Cretaceous}

The presence of foraminifera together with nannofossils (195B-3) and radiolarians together with nannofossils (195B-1, 195B-2, 196-3, and 196-4), all of Neocomian age, is of considerable significance.

For the nannofossils Thierstein's (1971) zonation of southwestern France is used rather than the nannofossil ranges obtained from the Blake Plateau (Worsley, 1971). These were only relative ranges, without parallel age indications, and are thus overruled by the zonation of Thierstein. The nannofossils are rather poorly preserved, and therefore only a selection of species controlled by facies or selective dissolution was observed. This limits the stratigraphic resolution. Stratigraphically important species are "Cretarhabdus crenulatus" (sensu Thierstein), Cruciellipsis cuvillieri, and Markalius circumradiatus, which date the age of sediments as Valanginian to early Hauterivian.

The foraminifera are represented by diverse species with calcareous and agglutinated test (species of Lenticulina, Dentalina, Lingulina, Frondicularia, Spirillina, Dorothia, etc.). This assemblage of foraminifera has been established earlier in limestones on the western slope of the Shatsky Rise (Leg 6) where the age of sediments was determined as upper Hauterivian-lower Barremian. 


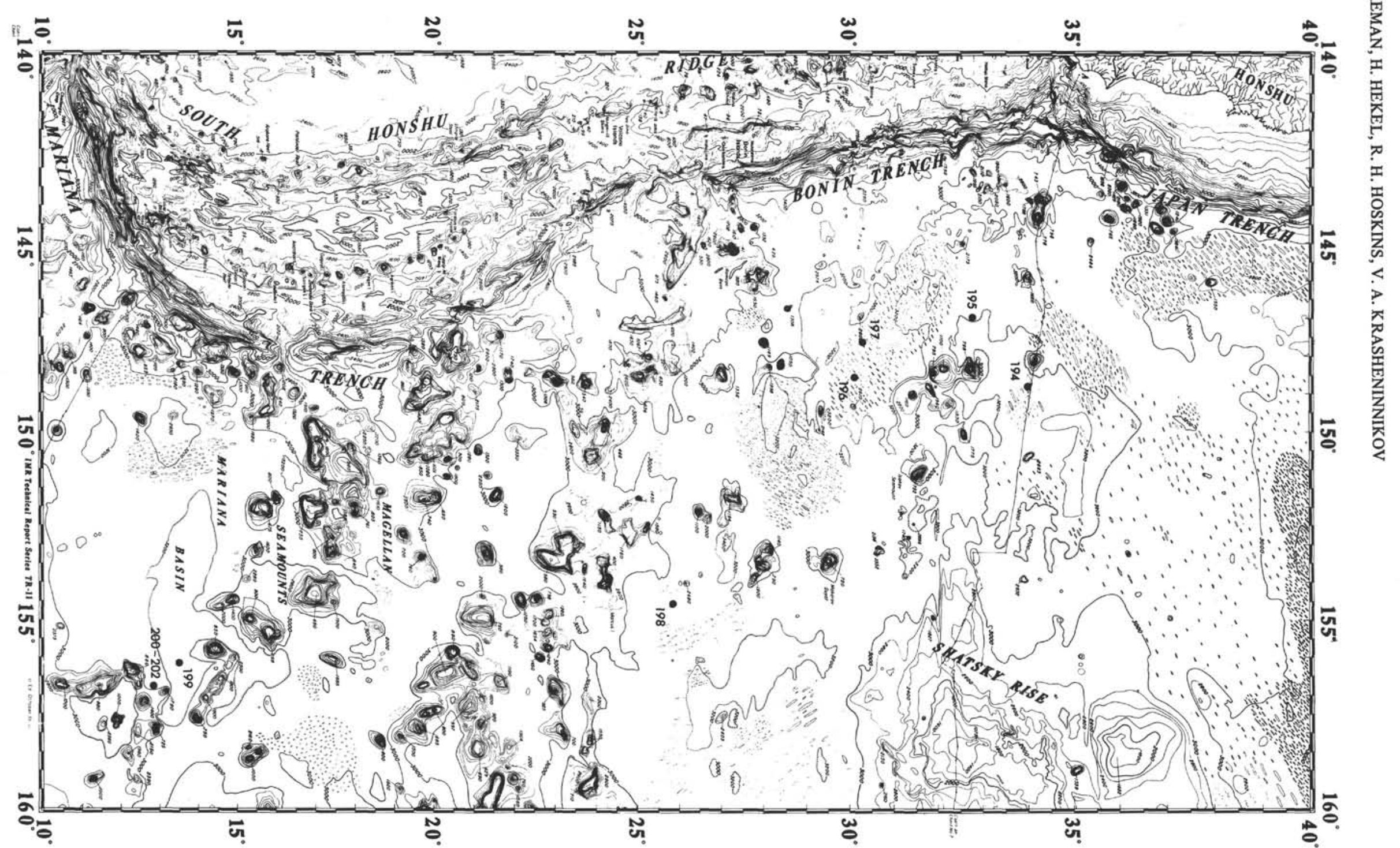

Figure 1. Leg 20 site locations and generalized bathymetry. Contour interval in fathoms (uncorrected for sound velocity); from bathymetry of the Northwest Pacific, sheet 3. Scripps Institution of Oceanography and Undersea Surveillance Oceanographic Center. 
BIOSTRATIGRAPHIC SYNTHESIS

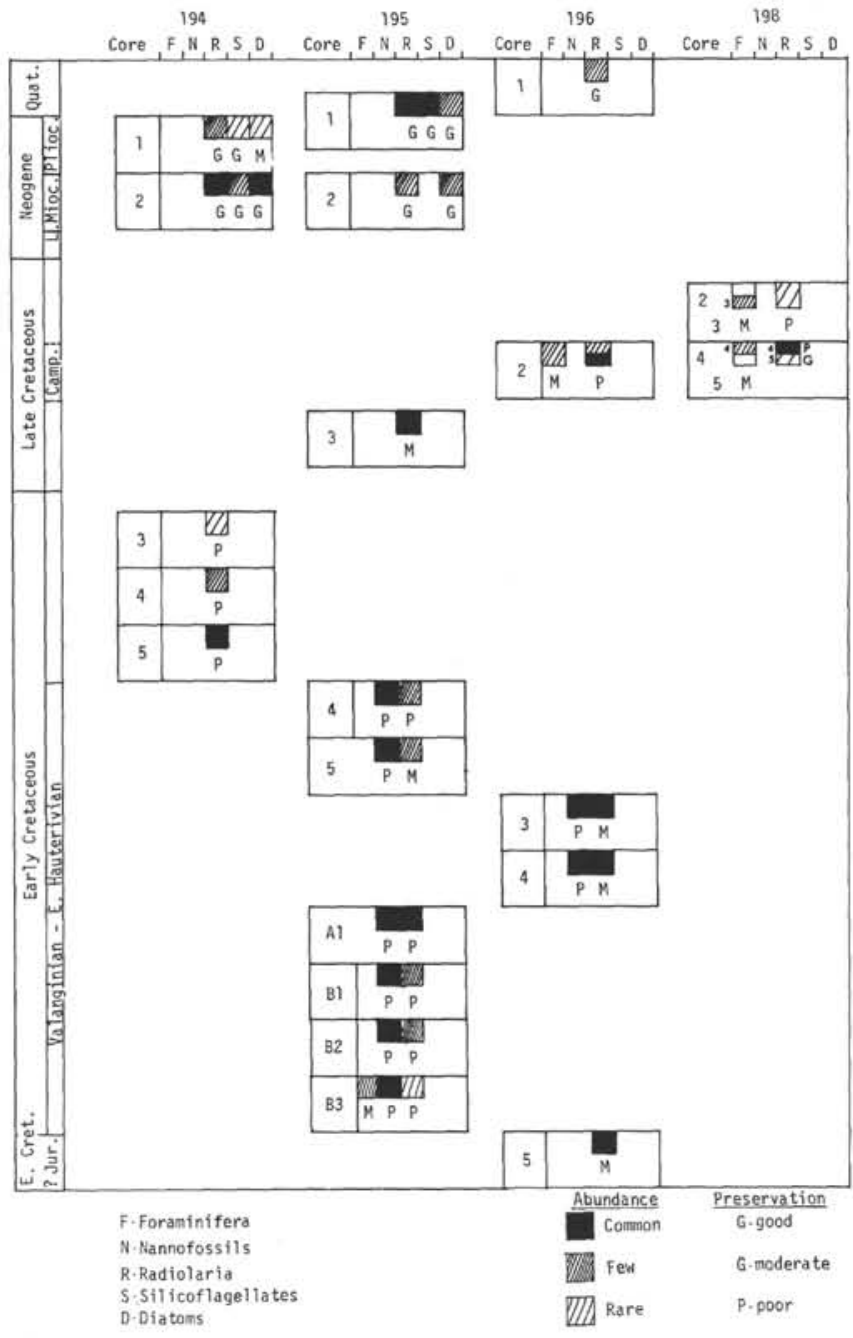

Figure 2. Abundance and preservation of various fossil groups encountered in Holes 194 to 196 and 198.

The radiolarian fauna is very similar to one illustrated by Fischli (1916) which he considered to be Early Cretaceous in age. Species in common include Staurosphaera septemporata, Acanthocircus dizonius (?), A. trizonalis, and Podobursa triacantha. S. septemporata has also been reported from the Hauterivian-Barremian by Cita and Pasquaré (1959), and Lozyniak (1969) illustrated common Podobursa in a fauna he considered to be of Neocomian age. These similarities form the basis for the Neocomian age assigned to the radiolarian-bearing samples listed above. One other sample, 196-5, CC, which does not cooccur with calcareous fossils, is considered to be older (Early Cretaceous-?Late Jurassic). It lacks $S$. septemporata and contains, among others, Sethocapsa cetia, Emiluvia pessagnoi, and Triactoma tithonianum which do not range up to the next younger samples.

\section{Late Cretaceous}

Foraminifera and Radiolaria cooccur in red clays in Cores 196-2, 198-3, and 198-4. The foraminifera are represented by a very peculiar assemblage of agglutinated

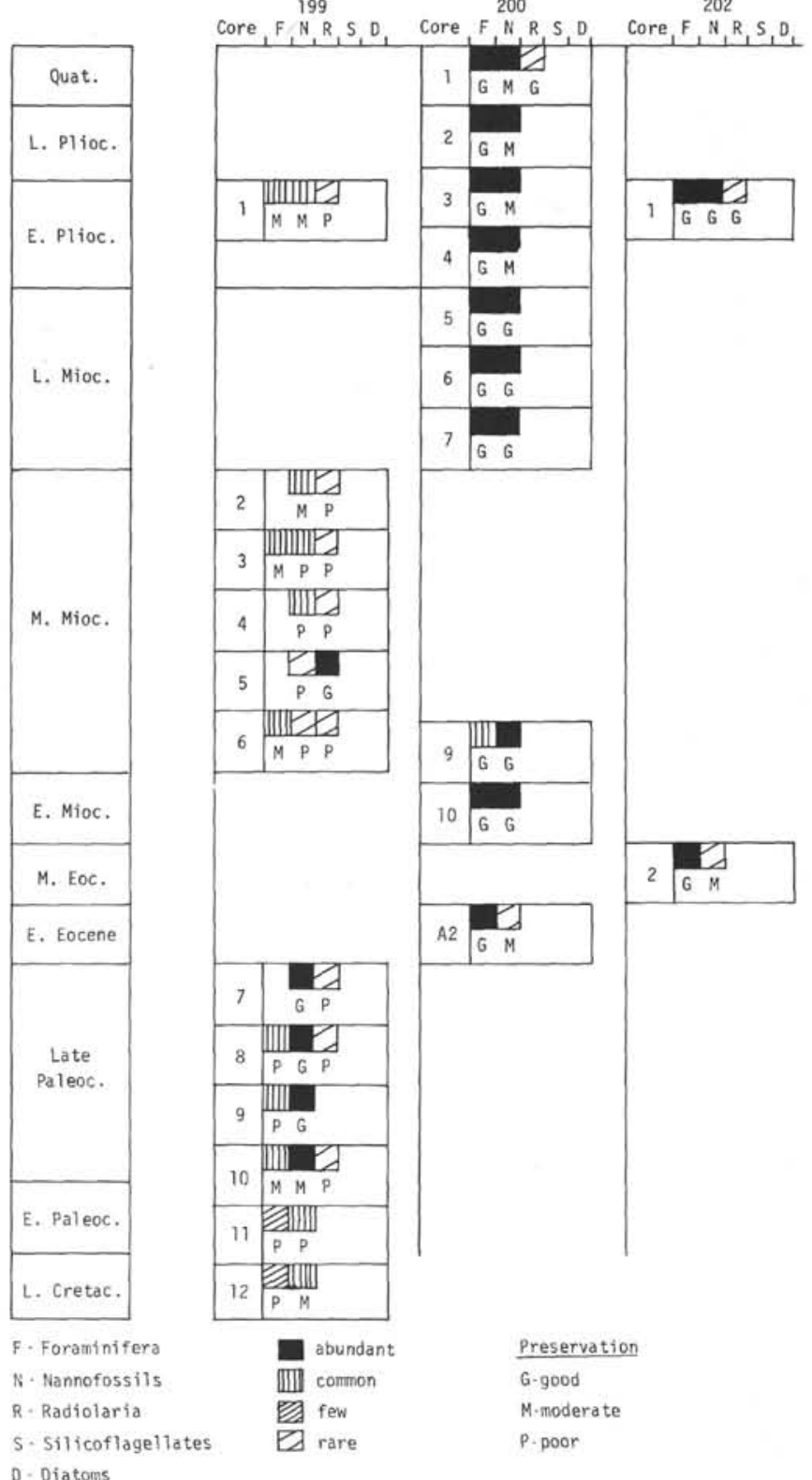

Figure 3. Abundance and preservation of various fossil groups encountered in Holes 199, 200, and 202.

(siliceous) forms with semitransparent walls. These foraminifera are not known from Late Cretaceous continental sediments, obviously because of the lack of deep-water sediments of this type, and are considered to be of Santonian-Campanian age. Practically all the observed species of Ammodiscus, Plectorecurvoides, Bolivinopsis, Pseudobolivina, Haplophragmoides, Labrospira, Paratrochamminoides, and the genus Praecystammina are new.

Radiolarian species in Core 196-2 are few and consist mainly of two species of Dictyomitra, one undescribed and the other, Dictyomitra torquata. Both are known from Campanian age sediments and a similar age is thus assigned. Cores $198-4$ and $198-5$ contain a richer fauna among which are D. torquata, Amphipyndax enesseffi, and Theocampe salillum, indicating an early Campanian age. Radiolaria in 
Hole 194

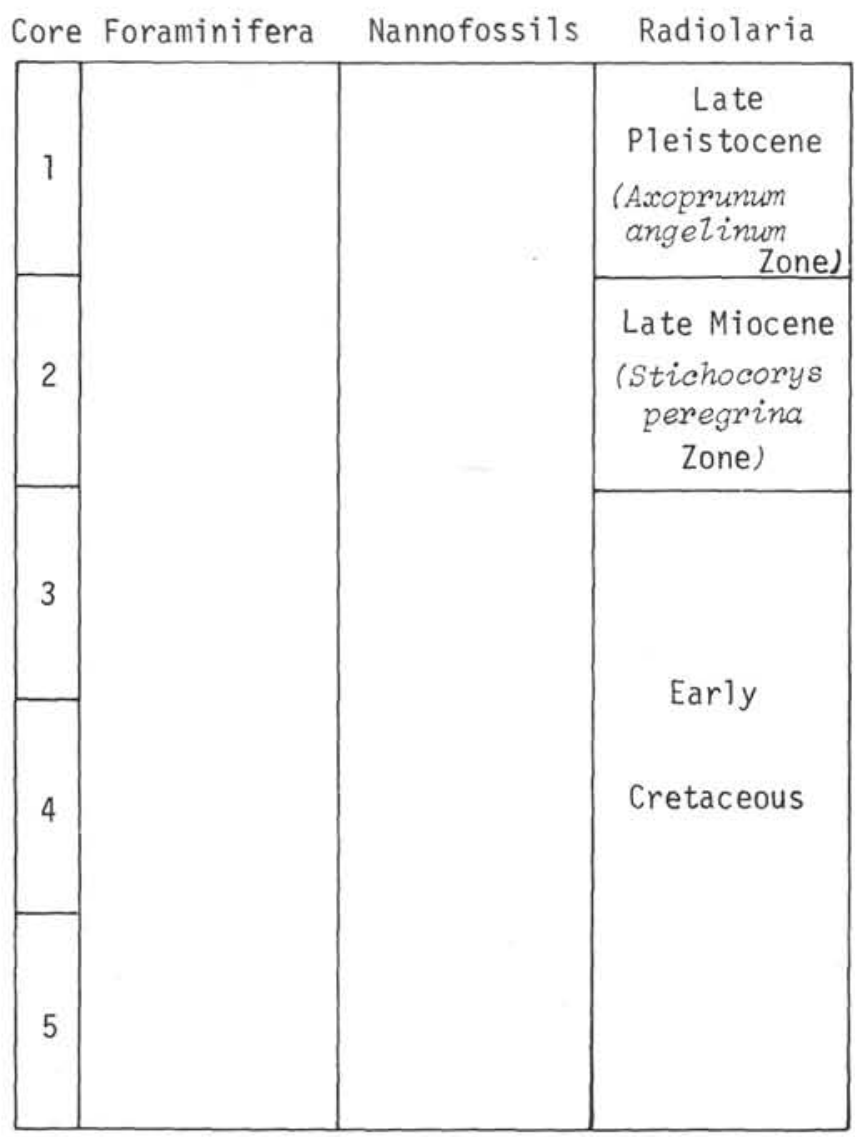

Figure 4. Stratigraphic age and zonal assignments as determined by foraminifera, nannofossils, and radiolarians for Sites 194 to 196, 198 to 200, and 202.

Cores 198-2 and 198-3 contain a richer fauna among which are D. torquata, Amphipyndax enesseffi, and Theocampe salillum, indicating an early Campanian age. Radiolaria in Cores $198-2$ and $198-3$ are too poorly preserved to identify precisely and they are considered to be Late Cretaceous on the basis of the early Campanian age assigned to Core $198-4$.

Late Cretaceous foraminifera and nannofossils are found together in the lower part of the chalk-chert section of Hole 199. In Core 12 and Core 11, Section 2, foraminifera seem to be only an impoverished remnant of the common rich assemblages usually found at this interval. Core 11, Section 2 is diverse enough to specify the Abathomphalus mayaroensis Zone. With nannofossils, the Tetralithus trifidus Zone is recognized in Core 12, and the Lithraphidites quadratus-Micula mura zonal interval in Core 11, Section 2 and core catcher. In Core 11 the boundary is situated between the Late Cretaceous and the topmost Maastrichtian or Danian, respectively, A. mayaroensis "Gl." eugubina zones according to foraminifera, and $M$. mura - Cruciplacolithus tenuis zones according to nannofossils.

\section{Latest Maastrichtian or Danian}

The cooccurrence of the "Globigerina" eugubina Zone and the Cruciplacolithus tenuis Zone is observed in a
Hole 195

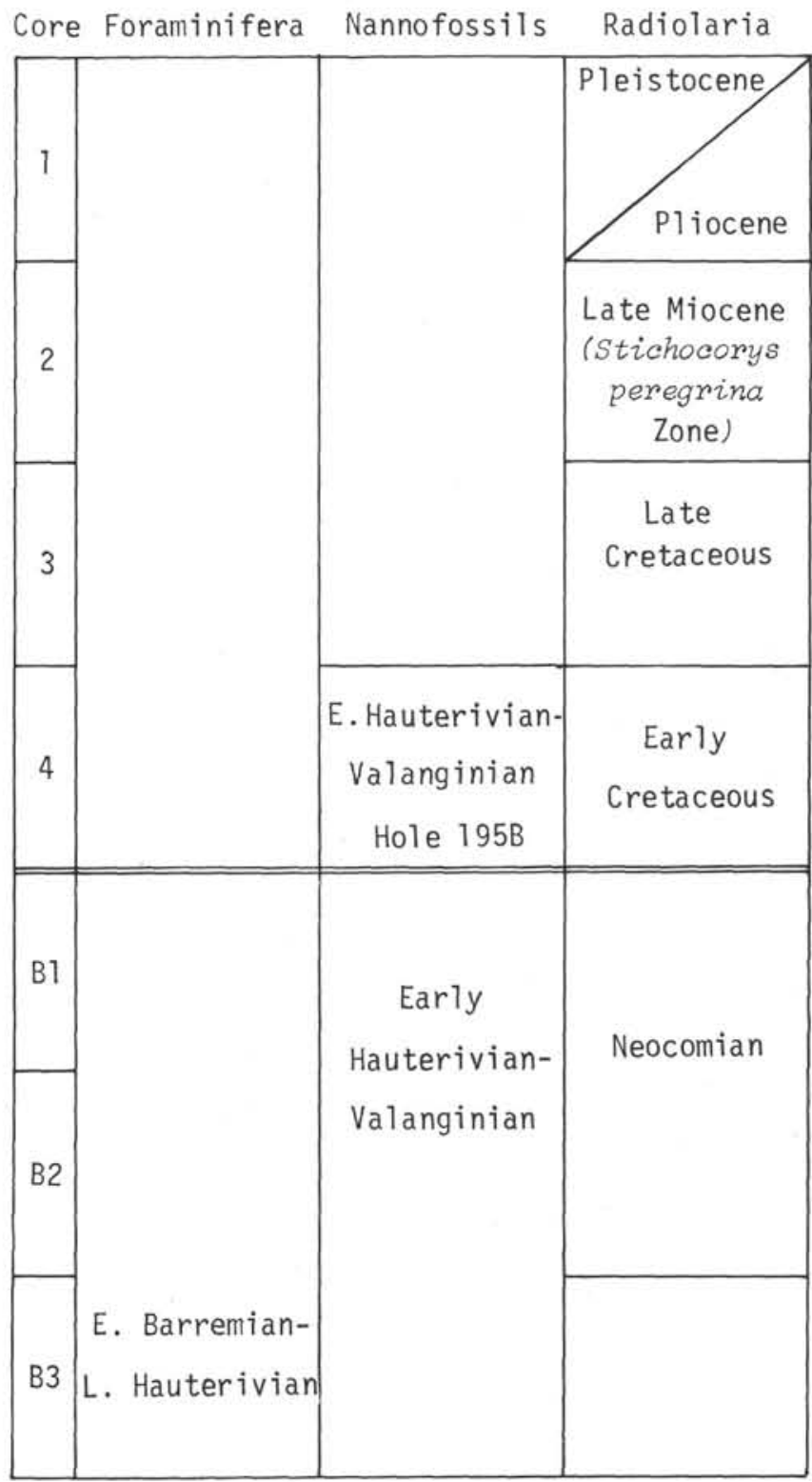

Figure 5. Stratigraphic age and zonal assignments as determined by foraminifera, nannofossils, and radiolarians for Sites 194 to 196, 198 to 200, and 202.

sequence of considerable thickness in Hole 199. Both foraminifera and nannofossil associations contain a substantial proportion of Late Cretaceous specimens. The coccoliths include species which are obviously reworked, as their highest known occurrence is below the top of the Cretaceous (Tetralithus trifidus, Arkhangelskiella parca). Obvious redeposition of Late Cretaceous is also observed in the late Paleocene. So the question of the presence of Cretaceous species in the "Gl." eugubina and earliest $C$. tenuis zones cannot be solved satisfactorily. In case all Cretaceous fossils are reworked, a substantial part of the sediment volume consists of derived sediments, requiring a very efficient method of redeposition. No obvious sedimentological evidence for turbidite sedimentation is found in this chalk-chert interval. 
Hole 196

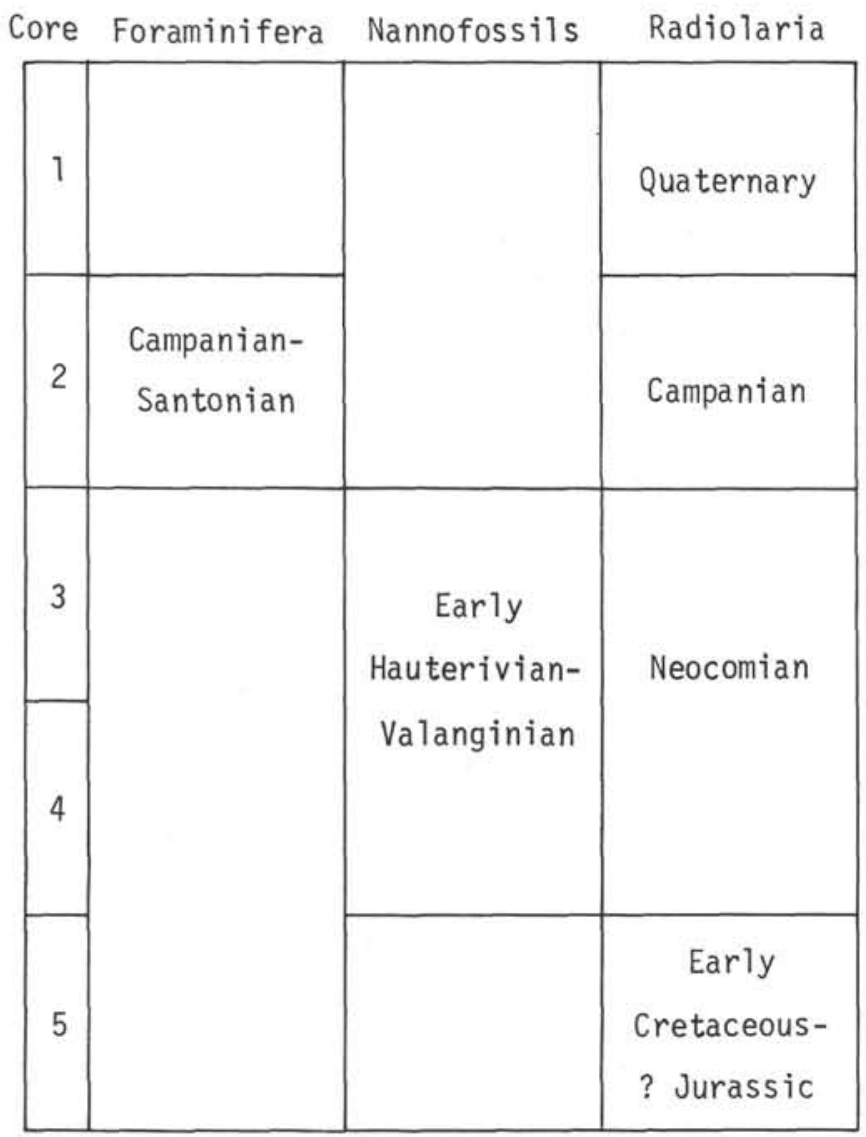

Figure 6. Stratigraphic age and zonal assignments as determined by foraminifera, nannofossils, and radiolarians for Sites 194 to 196, 198 to 200, and 202.

\section{Late Paleocene}

In Cores 7 to 10 of Hole 199 the Discoaster multiradiatus Zone is found cross-correlated with the upper part of the Globorotalia pseudomenardii Zone and the Globorotalia velascoensis Zone. The limit between the subzones of the D. multiradiatus Zone (Chiasmolithus bidensCampylosphaera eodela) is shown with a dotted line, as the influence of reworking of older sediments limits the accuracy of detailed correlation. The cooccurrence of these zones corresponds with the findings of several workers (Gohrbandt, Papp, and Stradner, 1963; Hay et al., 1967). Only in DSDP Hole 44 (Leg 6) the D. multiradiatus Zone has been found corresponding with the younger Globoratalia subbotinae Zone (Bukry et al., 1971).

\section{Eocene}

The samples of strongly winnowed foraminiferal sands from Holes 200A and 202 consist predominantly of excellently preserved foraminifera, while only traces of the nannufossil fraction are available, resulting in the type of foraminiferal quicksand which is a considerable drilling hazard.

In Hole 202, Core 2, the Orbulinoides beckmanni Zone could be found together with traces of the Discoaster
Hole 198

Core Foraminifera Nannofossils Radiolaria

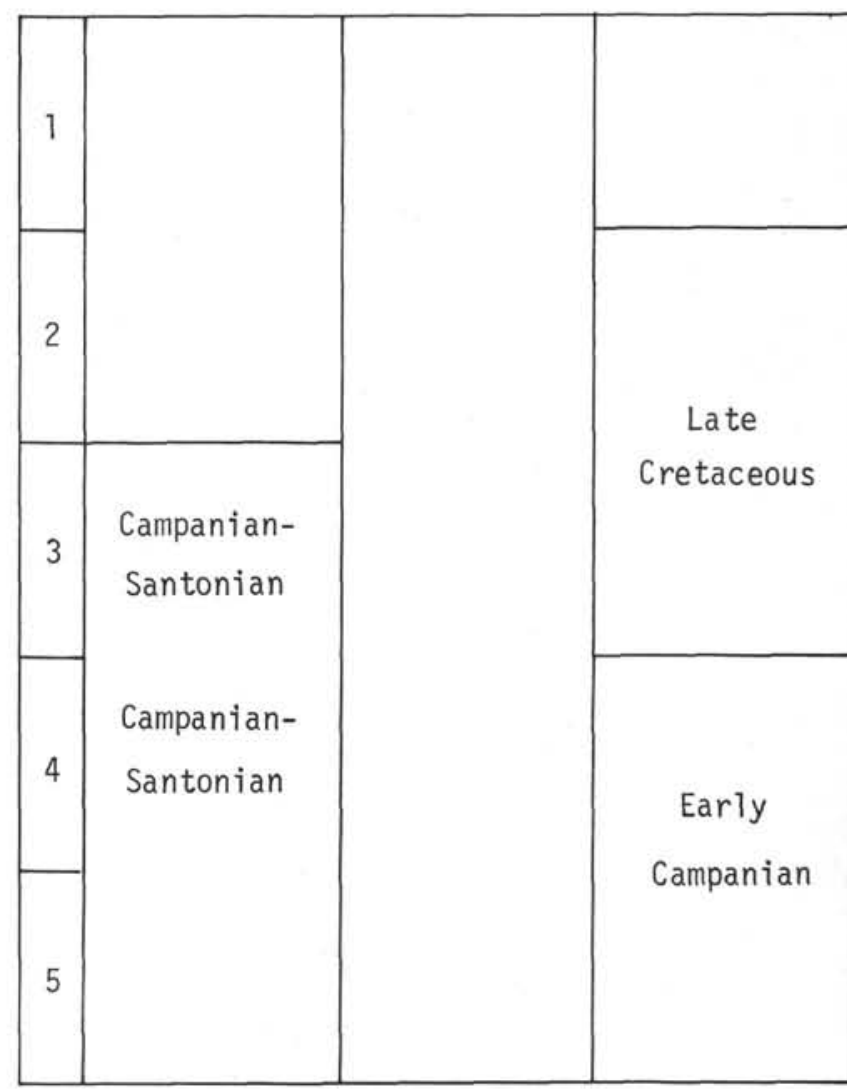

Figure 7. Stratigraphic age and zonal assignments as determined by foraminifera, nannofossils, and radiolarians for Sites 194 to 196, 198 to 200, and 202.

saipanensis Subzone of the Reticulofenestra umbilica Zone; while in Hole 200A, Core 2 the Globorotalia formosa formosa Zone (the uppermost part, transitional to the Globorotalia aragonensis Zone) has been found with questionable traces of the D. lodoensis Zone.

\section{Miocene-Pliocene-Pleistocene}

The succession of assemblages of planktonic foraminifera and nannoplankton found in calcareous oozes of Holes 200 and 200A confirms the standard zonation of Neogene and Pleistocene by means of these groups of microfossils established in other regions of the world.

Correlation of foraminiferal and nannoplankton zones is more or less the same as in previous legs, but the samples are from soupy oozes, and usually only the bottom of the core barrels could be sampled. The possibility of uphole contamination must be kept in mind therefore and can explain slight discrepancies in drawing stratigraphic boundaries which are based on planktonic foraminifera and nannoplankton. The significance of these discrepancies, however, should not be exaggerated. They can be connected also with a different understanding of such important stratigraphic levels as the lower Miocene-middle Miocene boundary (the age of Zone N.8) and the MiocenePliocene boundary (the age of Zone N.18). 


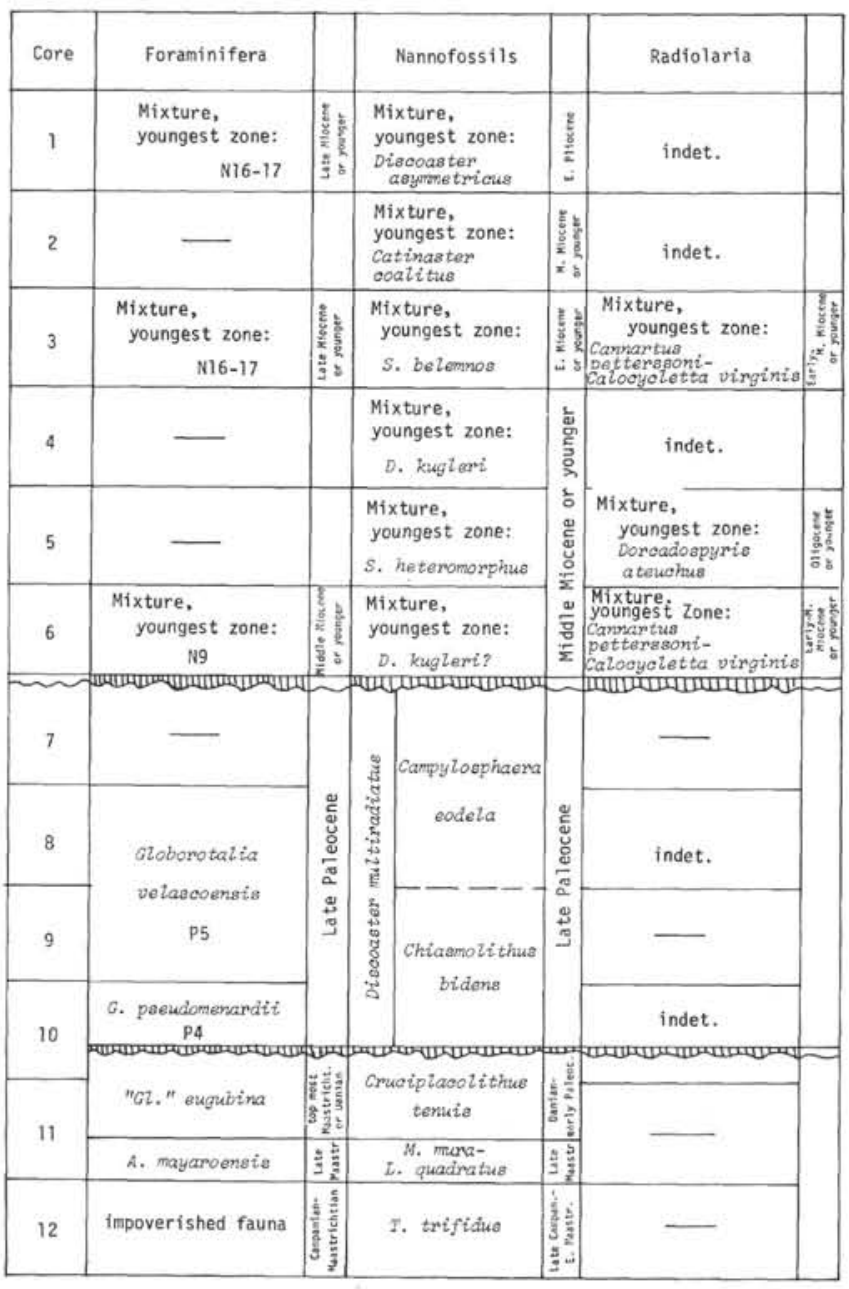

Figure 8. Stratigraphic age and zonal assignments as determined by foraminifera, nannofossils, and radiolarians for Sites 194 to 196, 198 to 200, and 202.

The Miocene-Pliocene boundary is widely accepted to be the Sphaeroidinella datum (N.18-N.19 boundary). The most important event around this time concerning nannofossils is the appearance of birefringent ceratoliths $(C$. amplificus, $C$. rugosus). These fossils have been found at the same level as the Sphaeroidinella datum (Bukry, 1973) and somewhat below this level (Gartner, 1969; Martini, 1971). At Site 200 these fossils are also below the Sphaeroidinella datum. As Bukry's zonation scheme has been followed, a somewhat lower boundary between Miocene and Pliocene is shown in the nannofossil chapter elsewhere in this report.

Neogene Radiolaria do not cooccur with calcareous fossils at any of the sites sampled on Leg 20. In Hole 194, Cores 1 and 2 are assigned to the late Pleistocene (Axoprunum angelinum Zone) and the late Miocene (Stichocorys peregrina Zone), respectively. Hole 195, Core 1 is considered to be at the Pleistocene-Pliocene boundary, and Core 2 to be late Miocene (Stichocorys peregrina Zone). Core 196-1 is assigned to the Quaternary.

\section{REWORKING AND STATE OF PRESERVATION}

Important observations illuminating the regional setting could be made with the finding of very well preserved

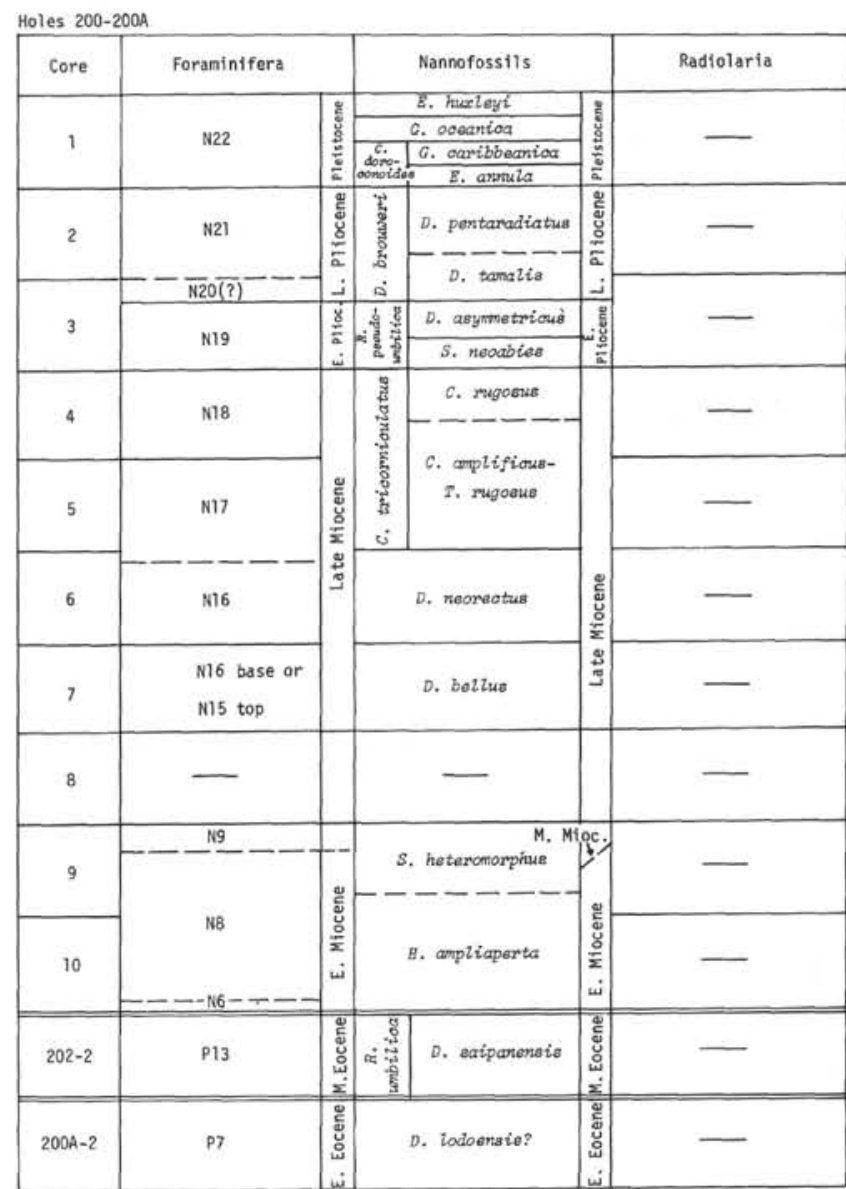

Figure 9. Stratigraphic age and zonal assignments as determined by foraminifera, nannofossils, and radiolarians for Sites 194 to 196, 198 to 200, and 202.

Maastrichtian foraminifera in the late Paleocene of Hole 199. In the Cretaceous section of the hole itself, foraminifera are rather scarce, with thin transparent walls and traces of dissolution. This association seems to be a remnant of common rich complexes of these planktonic microorganisms, being related to the process of selective dissolution while being deposited close to the depth of carbonate compensation. The limestone consists predominantly of nannofossils which are more resistant against selective dissolution.

The redeposition of the Cretaceous sediments seems to proceed during erosion of carbonate oozes of the Maastrichtian on the slopes of adjacent guyots. Thus, the slopes of guyots were considerably higher than the level of the carbonate compensation, and organogenous oozes of the Maastrichtian contain standard assemblages of planktonic foraminifera, while the oceanic floor (in the area of Hole 199) was situated at this time at depths similar to the level of carbonate compensation, with planktonic foraminifera being sporadic due to selective dissolution.

\section{REFERENCES}

Bukry, D., 1973. Initial Reports of the Deep Sea Drilling Project, Volume XVI: Washington (U.S. Government Printing Office). 


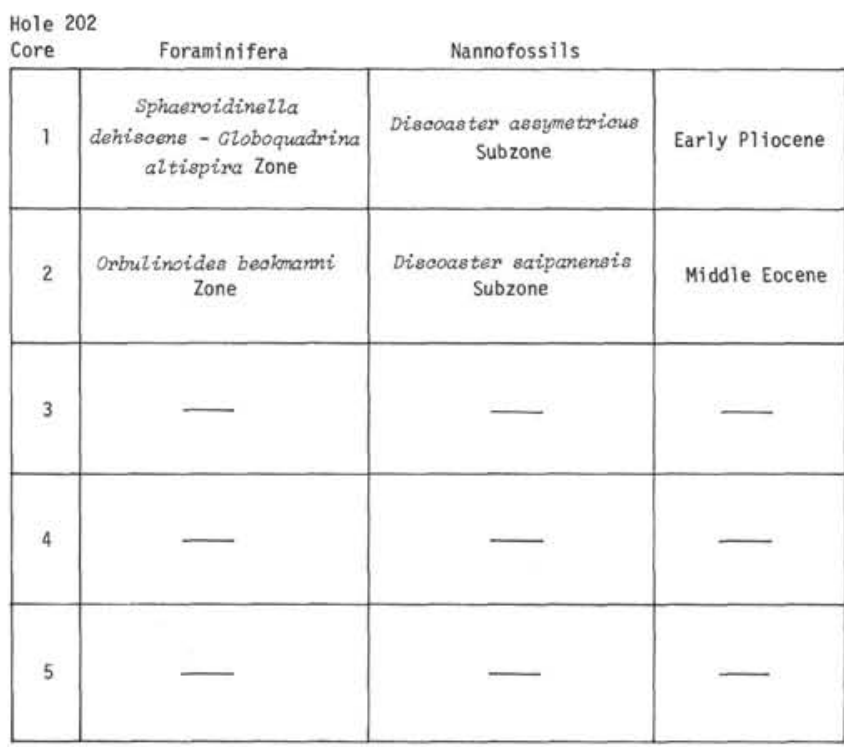

Figure 10. Stratigraphic age and zonal assignments as determined by foraminifera, nannofossils, and radiolarians for Sites 194 to 196, 198 to 200, and 202.

Bukry, D., Douglas, R. G., Kling, S. A., and Krasheninnikov, V., 1971. Planktonic microfossil biostratigraphy of the northwestern Pacific Ocean. In Fischer, A. G., Heezen, B. C., et al., Initial Reports of the Deep Sea Drilling Project, Volume VI: Washington (U.S. Government Printing Office). p. 1253.
Cita, M. B. and Pasquaré, G., 1959. Osservazioni micropaleontologiche sul Cretaceo delle dolomiti: Riv. Ital. Paleontol. Stratigr. v. 65, p. 385.

Fischli, H., 1916. Beitrag zur Kenntnis der fossilen Radiolarien in der Riginagelfluh: Mitt. Naturwiss. Ges. Winterthur, v. 11, p. 44.

Gartner, S., 1969. Correlation of Neogene planktonic foraminifera and calcareous nannofossil zones: Gulf Coast Assoc. Geol. Soc. Trans., v. 19, p. 585.

Ghorbandt. K., Papp, A., and Stradner, H., 1963. Zur Gliederung des Paläogen im Helveticum nördlich Salzburg nach planktonischen Foraminifera; Mitt. Geol. Ges. Wien., v. 56, p. 1 .

Hay, W. W., Mohler, H. P., Roth, P. M., Schmidt, R. R., and Boudreaux, J. E., 1967. Calcareous nannoplankton zonation of the Cenozoic of the Gulf Coast and CaribbeanAntillean area and transoceanic correlation: Gulf Coast Assoc. Geol. Soc. Trans., v. 17, p. 428.

Lozyniak, P. Yu., 1969. Radioliarii nizhnemelovykh otlozhenii Ukrainskikh karpat. [Radiolaria of the Lower Cretaceous sediments of the Ukranian Carpathians]: In Iskopaemyei sovremennye Radioliarii [Fossil and Recent radiolarians]. Vialov, O. C. (Ed.), L'vov. Geol. O-vo, L'vov. Univ. 29.

Martini, E., 1971. Standard Tertiary and Quaternary calcareous nannoplankton zonation: Plankt. Conf. 2nd Roma, Proc., p. 739-785.

Thierstein, H. R., 1971. Tentative Lower Cretaceous calcareous nannoplankton zonation: Ecol. Geol. Helv., v. 64 , p. 459

Worsley, T., 1971. Calcareous nannofossil zonation of Upper Jurassic and Lower Cretaceous sediments from the western Atlantic: Plankt. Conf. 2nd Roms Proc., v. 2, p. 1301 .

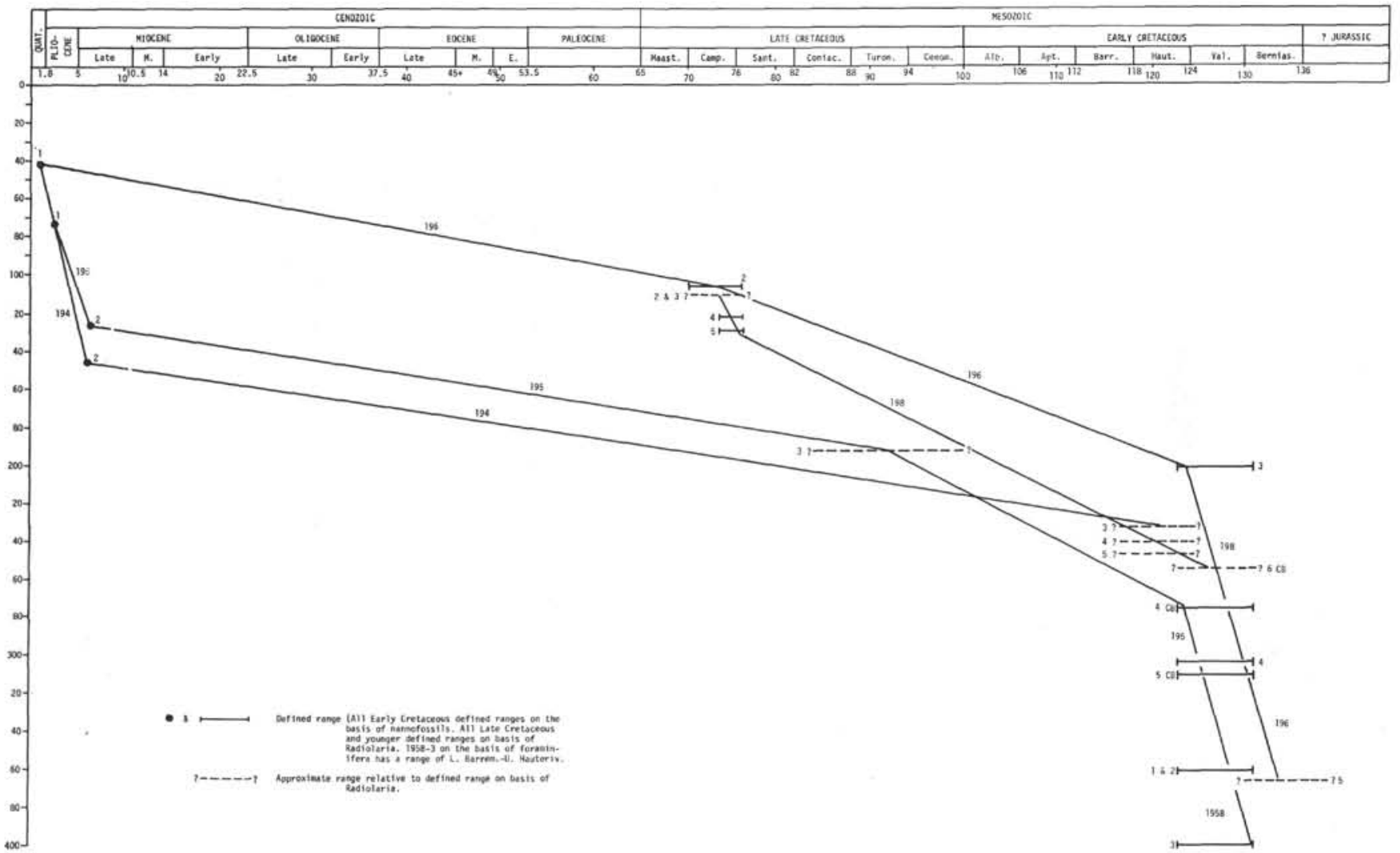

Figure 11. Plots of age vs. depth for Leg 20 sites in the abyssal Western Pacific. 